\title{
Sublethal Effects of Atropa belladonna Herbal Extract on Biological Performance of the Two-Spotted Spider Mite Tetranychus urticae Koch (Acari: Tetranychidae)
}

\author{
Ayad Alsendi ${ }^{1}$, Mohammadreza Havasi ${ }^{1} \&$ Niloufar Sangak Sani Bozhgani ${ }^{1}$ \\ ${ }^{1}$ Department of Entomology and Plant Pathology, Aburaihan Campus, University of Tehran, Tehran, Iran \\ Correspondence: Mohammadreza Havasi, Department of Entomology and Plant Pathology, Aburaihan Campus, \\ University of Tehran, Tehran, Iran. E-mail: mohammadrezahavasi96@gmail.com
}

Received: January 9, 2018

Accepted: May 6, 2018 Online Published: June 15, 2018

doi:10.5539/jas.v10n7p230

URL: https://doi.org/10.5539/jas.v10n7p230

\begin{abstract}
The two-spotted spider mite, Tetranychus urticae Koch (Acari: Tetranychidae) is one of the most important pests of agricultural products. Using chemical pesticides is one of the main methods for its management. Due to undesirable effects of synthetic pesticides, this research was conducted to achieve alternative safe compounds. In this study sublethal effect of Atropa belladonna herbal extract including $\mathrm{LC}_{10}, \mathrm{LC}_{20}, \mathrm{LC}_{30}$ and distilled water were evaluated on biological parameters (such as $r, \lambda, G R R, R_{0}$ and $T$ ) of $T$. urticae. The experiments were done under laboratory condition at $25 \pm 2{ }^{\circ} \mathrm{C}, 60 \pm 5 \% \mathrm{RH}$, and a photoperiod of 16:8 (L: D) hours. The crude data were analyzed based on age-stage, two-sex life table analysis. The results indicated significant reduction in female's duration of maturation, oviposition period and total fecundity by increasing examined dose. The highest and lowest values of the net reproductive rate $\left(R_{0}\right)$ were obtained 38.41 and 18.08 offspring/individual in control and $\mathrm{LC}_{30}$, respectively. The maximum values of intrinsic rate of increase $(r)$ was 0.2201 day $^{-1}$ that occurred on control treatment while the minimum values was obtained 0.1937 day ${ }^{-1}$ in $\mathrm{LC}_{30}$ concentration. Finite rate of increase $(\lambda)$ had significantly descended with concentration enhancing from $\mathrm{LC}_{20}$ to $\mathrm{LC}_{30}$, compared with the control. The results demonstrated that Atropa belladonna herbal extract could be incorporated in integrated pest management (IPM) programs of T. urticae.
\end{abstract}

Keywords: Atropa belladonna, Tetranychus urticae, life table parameters, sublethal effects

\section{Introduction}

The two-spotted spider mite, Tetranychus urticae Koch (Acari: Tetranychidae), is an serious pest of many greenhouse plants and field crops (Cote et al., 2002; Sedaratian et al., 2009; Khanamani et al., 2013; Maleknia et al., 2016). The phytophagous mite T. urticae damage may include webbing, fine stippling, leaf yellowing, leaf crop, and even plant death (Helle \& Sabelis, 1985). This pest with a short life span, high reproductive ability, multiple births and plant nutrition can stop plant growth and reduce the quality and quantity of the crop (Saeedi \& Arbabi, 2007). In severe infection a large amount of thin webbing is produced that may completely cover infested areas of leaves (Zhang, 2003). Control of this mite species is obviously difficult and mostly relies on the use of pesticides (Zhao, 2000).

The wide use of pesticides leads to affect non-target organisms (Croft, 1990), human safety (Garcia-Marı \& Gonzalez-Zamora, 1999), the emergence of secondary pests (Elzen, 2001) and development of resistance (Brattsten et al., 1986). Also because of the adverse effect of pesticide use, alternative control methods are being researched for T. urticae (Yorulmaz et al., 2014). Plant compounds such as extracts were used as insecticides (Ofuya \& Okuku, 1994; Kim et al., 2003), acaricidals (Rim \& Jee, 2006; Fernandes \& Freitas, 2007). The Atropa belladonna L. (Solanaceae) is a perennial herb that is cultivated throughout the world. This plant belongs to the Caspian region and grows on the edge of forests and sub-trees. The geographical distribution of this species is in Europe, Turkey and northern Iran (Rita \& Animesh, 2011). The scientific name A. belladonna is one of the most important medicinal plants of the Solanaceae family (Berdai et al., 2012). It has natural habitats in the northern regions of Iran. The berries are sweet and are consumed by animals that disperse the seeds in their droppings, even though they contain toxic alkaloids (Kay, 1992). A number of studies have been conducted for evaluating the lethal and sublethal effects of various herbal extracts, on two-spotted spider mite (Choi et al., 2004; Wang et 
al., 2007; Kumral et al., 2010; Pavela, 2015), but no reports have been made about the effects of this plant extract on two-spotted spider mite. The effect of pesticides on insects usually is estimated in experimental conditions based on $\mathrm{LC}_{50}$. Sublethal effect studies have been used to assess the selectivity of pesticides to beneficial arthropods (Teodoro et al., 2005; Poletti et al., 2007).

However, the common method for estimating the effect of pesticides on insects only addresses the effects of lethality and mortality data, so demographic toxicological studies or toxicological evaluation tests on insect life table that provide more accurate information can be recommended. In these studies, the effects of pesticides on a (homogeneous) same age group of survivors from the impact of the pesticide are investigated and the survival, fecundity and mortality of this group are studied until the end of lifespan. It also provides a measure of population growth rates. The use of the inherent rate of population increase as a biometric parameter has been recommended in toxicological studies (Boykin \& Campbell, 1982). Therefore, in predicting the effect of pesticide on the insect, life-history tests are more reliable than their lethal dose estimation. Only essential oils derived from some plants can be good alternative methods to controlling this pest. Essences, secondary metabolites of plants with aromatic compounds, have low molecular weight compounds and volatile compounds with proven pesticide properties (Bakkali et al., 2008). A number of essential oils act selectively and do not affect non- target organisms. So far the properties of several herbal essential oils are studied for controlling two-spotted spider mite (Cavalccanti et al., 2010; Han et al., 2010). Also, many studies have been done on the sublethal effects of herbal essential oils, such as repulsion effects, nutritional inhibition, breeding prevention and breeding (Choi et al., 2004). Many of these plant compounds are able to affect the growth and reproduction parameters of pests and their various growth stages (Tsolakis \& Ragusa, 2008). According to the researches done so far the effect of $A$. belladonna herbal extract has not been reported on two-spotted spider mite.

Consequently, taking the activity of this herbal extract, in this experiment, the effects of sublethal concentrations of Atropa belladonna herbal extract on T. urticae were investigated using demographic toxicological analysis. Being a part of systematic evaluation of the acaricidal potential of the plants, the objective of this study was to evaluate and validate the effects of sublethal concentrations of $A$. belladonna herbal extract on demographic parameters of T. urticae, to effective and low-risk control of two-spotted spider mite that is eco-friendly.

\section{Materials and Method}

\subsection{Host Plant Rearing}

Beans plants (phaseolus vulgaris L. var. Khomein) were planted as host plant for T. urticae rearing. The plants were reared in pots with $15 \mathrm{~cm}$ diameter under laboratory conditions at $25 \pm 2{ }^{\circ} \mathrm{C}, 60 \pm 5 \%$ R.H. and a photoperiod of 16:8 (L:D) hours.

\subsection{Mite Colonies}

Primary population of T. urticae was collected from infested greenhouses of rose with scientific name Rosa hybrida from greenhouse around Pakdasht (South eastern of Tehran, Iran) and then grown on beans planted in the greenhouse. The colony of T. uricae was placed in the growth chamber with a temperature of $25 \pm 2{ }^{\circ} \mathrm{C}$, a relative humidity of $60 \pm 5 \%$ and a photoperiod period of $16: 8 \mathrm{~h}$ (light:dark).

\subsection{Preparation of Herbal Extract}

The Atropa belladonna plants were collected from the forests of Golestan province. The leaves were first crushed and then 40 grams of leaves were extracted with ethanol ( 300 milliliters 70 percent) for 3 hours at each turn using Soxhlet device. The solvent was isolated using a rotary machine at 40 degrees Celsius at $120 \mathrm{rpm}$.

\subsection{Concentration-Response Bioassay}

To determine the effective dose of $A$. belladonna, were used five concentrations . The experiments were assessed according to leaf dip bioassay method (Helle \& Overmeer, 1985). The mortality covering the range of 10-90\%. The leaf discs were dipped for 15 seconds into solution of herbal extract. The control leaf discs were dipped in distilled water only. Then, leaf discs dried in room condition for about 3 hours. Twenty same age (24-h-old) adults mite (from both sexes) were transferred to leaf discs with a diameter of $3 \mathrm{~cm}$ and placed in Petri dishes with diameter of $6 \mathrm{~cm}$. Mortality of adult was evaluated after $24 \mathrm{~h}$. Mites were considered as dead if after touching with a small fine brush, they could not crawl and were non-functional. All experimentas were conducted in the laboratory condition at $25 \pm 2{ }^{\circ} \mathrm{C}, 60 \pm 5 \% \mathrm{RH}$ and a photoperiod period of 16:8 $\mathrm{h}$ (L:D). In this study four replicates were used for each concentration. There were five concentrations and four replicates per concentration. 


\subsection{Effect of Sublethal Concentrations on Biological Parameters of Offspring From Treated Females}

In order to evaluate the sublethal effects of A. belladonna herbal extract on T. uricae, bean leaf discs were treated with sublethal concentrations including $\mathrm{LC}_{10}, \mathrm{LC}_{20}, \mathrm{LC}_{30}$ and allowed to dry for $2 \mathrm{~h}$. One hundred same-aged (24-h-old) gravid females were used for each treatment. After 24 hours, the surviving females were separately transferred to leaf disc with $3 \mathrm{~cm}$ diameter on wet filter paper in Petri dishes. After 24 hours, one egg as the basis was placed in each Petri dish and other eggs laid by female and mite were removed from Petri dish.

The newly-emerged females were coupled with males for mating after the adult emergence. Finally, the fecundity of females was daily recorded and population parameters were calculated in both male and females until the death of the last sample. In order to avoid creating tension in mites (due to aging) leaves of beans were replaced by fresh leaves every $48 \mathrm{~h}$. The Petri dishes were checked every 24 hours and changes such as developmental time and survival of them were recorded until the death of the last female.

\subsection{Data Analysis}

The value of $\mathrm{LC}_{50}$ and sublethal concentrations, was calculated using the software SPSS ver. 19.0. To compare the significance of the $\mathrm{LC}_{50} 95 \%$ of the confidence interval were used. The raw data obtained from the two-spotted spider mite life cycle for analyzing and determining the parameters of the life table according to the Chi (1988), and Chi and Liu (1988) by using the computer program, TWO-SEX_MsChart (Chi, 2016). The means of the latter parameters were compared by using the paired bootstrap test at the $5 \%$ significance level (Riahi et al., 2017; Khanamani et al., 2017). Differences between means were compared with the Turkey's test was carried out using SAS (SAS Institute 2002). The age-specific fecundity $\left(m_{x}\right)$, age-specific survival rate $\left(l_{x}\right)$, age-stage specific survival rate $\left(S_{x j}\right)$ (where, $x=$ age in day and $j=$ stage) and the population growth parameters were calculated accordingly:

$$
m_{x}=\frac{\sum_{j=1}^{k} S_{x j} f_{x j}}{\sum_{j=1}^{k} S_{x j}}
$$

where, $k$ is the number of stages.

$$
l_{x}=\sum_{\mathrm{j}=1}^{\mathrm{k}} \mathrm{S}_{\mathrm{xj}}
$$

The intrinsic rate of increase is estimated by using the iterative bisection method from the following equation:

$$
\sum_{x=0}^{k} \mathrm{e}^{-r(x+1)} \cdot l_{x} m_{x}=1
$$

with age indexed from 0 to $\omega$ (Goodman, 1982).

Other parameters $\left(R_{0}, \lambda, T, G R R\right.$ and $\left.D T\right)$ were calculated by the following equations:

$$
\begin{gathered}
R_{0}=\sum_{x=0}^{\omega} \sum_{j=1}^{k} S_{x j} f_{x j} \\
\lambda=\mathrm{e}^{r m} \\
T=\frac{\ln R_{0}}{r_{m}}
\end{gathered}
$$

The GRR was calucted as (Fathipour \& Maleknia, 2016):

$$
G R R=\sum_{x=\mathrm{a}}^{\beta} m_{x}
$$

\section{Results and Discussion}

\subsection{Concentration-Response Bioassay}

The sublethal concentrations of Atropa belladonna herbal extract $\left(\mathrm{LC}_{10}, \mathrm{LC}_{20}\right.$ and $\left.\mathrm{LC}_{30}\right)$ for T. urticae were estimated to be (1650, 2300 and $3000 \mathrm{ppm})$, respectively. No mortality was observed in control. The value of $p$ is greater than 0.05 , indicating the biometric alignment of the lines, and the Chi-squared value also confirms it. 


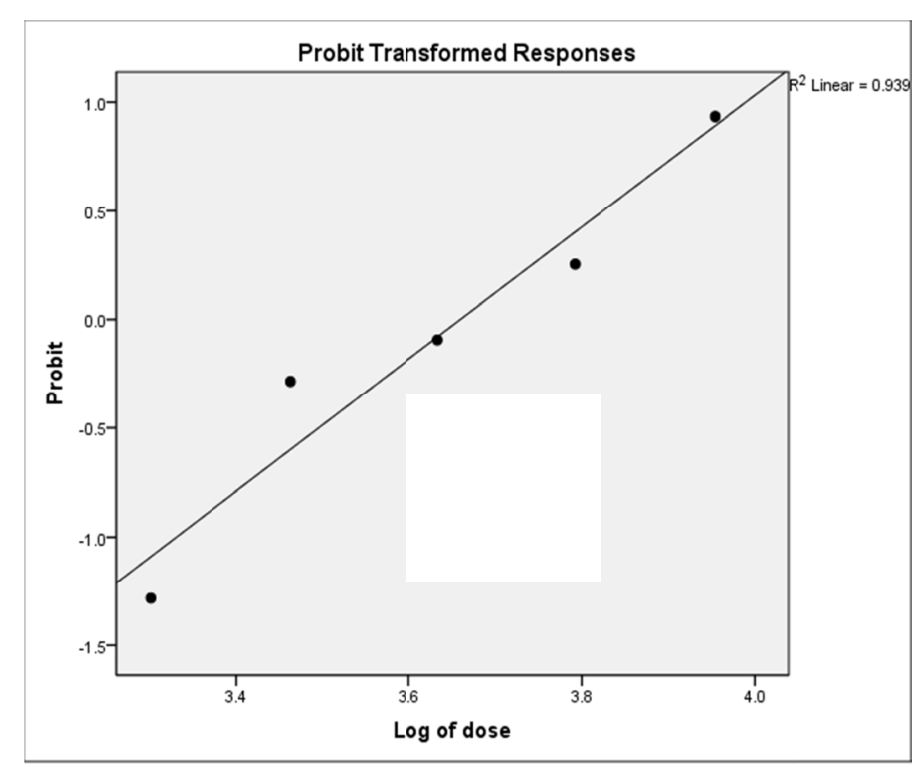

Figure 1. Dose-response curves of Tetranychus urticae mites treated with different doses of Atropa belladonna herbal extract

\subsection{Development time, Longevity and Total Life Span}

The impact of $A$. belladonna herbal extract at different stages of growth of two-spotted spider mite is mentioned in Table 1. The longest egg duration was recorded 4.21 days that belongs to $\mathrm{LC}_{10}$. However according to El-gengaihi et al. (2011) the length of egg duration of two-spotted spider mite in treatment with alcoholic extract of Dondonea viscosa L. was reported 4.3 days which are consistent with the length of egg stage period in treatment with A.belladonna herbal extract. The length of larval period in treatment mites does not show significant difference with control treatment. In the immature stages the sublethal concentration of the Atropa belladonna herbal extract does not show significant effect with control. Duration of egg, larval, and deutonymph for both sexes demonstrated the no significant difference between control and experimental concentrations. In fact $A$. belladonna herbal extract had nontoxic effect in this period. But protonymph period markedly affected with $\mathrm{LC}_{30}$ in compare to other treatments. The longevity of treated male with $\mathrm{LC}_{20}$ and $\mathrm{LC}_{30}$ of haerbal extract was significant difference from control and $\mathrm{LC}_{10}$. By increasing concentration from $\mathrm{LC}_{10}$ to $\mathrm{LC}_{30}$ significantly reduced in longevity of treated females. The minimum value of total life span was obtained 18.83 and 19.35 days for male and female treated with highest concentration of haerbal extract.

The length of lifespan period in control, $\mathrm{LC}_{10}, \mathrm{LC}_{20}$ and $\mathrm{LC}_{30}$ concentrations for female mites, were 23.53, 22.44, $21.44,19.35(F=242.6, \mathrm{df}=3, P<0.0001)$ days, respectively. The control caused the most prolonged life time of T. urticae. 
Table 1. Effects of sublethal concentrations of Atropa belladonna herbal extract on developmental times, adult longevity, and total life span (day $\pm \mathrm{SE})$ of Tetranychus urticae

\begin{tabular}{|c|c|c|c|c|}
\hline Parameter & Control & LC10 & LC20 & LC30 \\
\hline \multicolumn{5}{|l|}{ Male } \\
\hline Egg (day) & $4.21 \pm 0.11 \mathrm{a}$ & $4.30 \pm 0.01 \mathrm{a}$ & $4.30 \pm 0.1 \mathrm{a}$ & $4.13 \pm 0.07 \mathrm{a}$ \\
\hline Larva(day) & $2.14 \pm 0.10 \mathrm{a}$ & $2.22 \pm 0.09 \mathrm{a}$ & $2.22 \pm 0.09 \mathrm{a}$ & $2.00 \pm 0.09$ \\
\hline Protonymph (day) & $2.14 \pm 0.10 \mathrm{a}$ & $2.26 \pm 0.09 \mathrm{a}$ & $2.26 \pm 0.09 \mathrm{a}$ & $2.09 \pm 0.12 \mathrm{a}$ \\
\hline Deutonymph (day) & $2.14 \pm 0.10 \mathrm{a}$ & $2.26 \pm 0.09 \mathrm{a}$ & $2.26 \pm 0.09 \mathrm{a}$ & $2.35 \pm 0.1 \mathrm{a}$ \\
\hline Longevity (day) & $10.21 \pm 0.15 \mathrm{a}$ & $9.70 \pm 0.12 \mathrm{a}$ & $9.13 \pm 0.17 b$ & $8.26 \pm 0.23 c$ \\
\hline Total life span (day) & $20.86 \pm 0.25 \mathrm{a}$ & $20.74 \pm 0.27 \mathrm{a}$ & $20.17 \pm 0.28 \mathrm{ab}$ & $18.83 \pm 0.34 b$ \\
\hline \multicolumn{5}{|l|}{ Female } \\
\hline Egg (day) & $4.19 \pm 0.06 \mathrm{a}$ & $4.21 \pm 0.05 \mathrm{a}$ & $4.18 \pm 0.05 \mathrm{a}$ & $4.11 \pm 0.04 \mathrm{a}$ \\
\hline Larva (day) & $2.15 \pm 0,05 \mathrm{a}$ & $2.17 \pm 0.05 \mathrm{a}$ & $2.12 \pm 0.05 \mathrm{a}$ & $2.06 \pm 0.04 \mathrm{a}$ \\
\hline Protonymph (day) & $2.30 \pm 0.07 \mathrm{a}$ & $2.15 \pm 0.04 \mathrm{a}$ & $2.11 \pm 0.04 \mathrm{ab}$ & $2.06 \pm 0.04 b c$ \\
\hline Deutonymph (day) & $2.15 \pm 0.05 \mathrm{a}$ & $2.09 \pm 0.04 \mathrm{a}$ & $2.09 \pm 0.04 \mathrm{a}$ & $2.02 \pm 0.05 \mathrm{a}$ \\
\hline Longevity (day) & $12.74 \pm 0.09 \mathrm{a}$ & $11.82 \pm 0.13 b$ & $10.94 \pm 0.015 \mathrm{c}$ & $9.11 \pm 0.08 \mathrm{~d}$ \\
\hline Total life span (day) & $23.53 \pm-0.13 a$ & $22.44 \pm 0.18 b$ & $21.44 \pm 0.17 \mathrm{a}$ & $19.35 \pm 0.12 \mathrm{~d}$ \\
\hline
\end{tabular}

Note. Means within a row followed by the same letter are not significantly different (Turkey-kramer $\mathrm{p}<0.05$ ).

\subsection{Reproduction}

According to Table 2 the duration of oviposition period in treated females with different concentrations significantly reduced in compared to control. However, no significant difference was observed for pre-oviposition period between untreated and treated cohort. In this study, an increase in the dosage of leaf extract was followed by a significant decrease in oviposition period. The shortest period of oviposition $(7.06[F$ $=542.3, \mathrm{df}=3, P<0.0001]$ days) was recorded for mites that treated with $\mathrm{LC}_{30}$ concentration and the longest oviposition time $(10.74[F=542.3, \mathrm{df}=3, P<0.0001]$ days $)$ was recorded for distilled water. Our findings showed that fecundity of female mites significantly decreased under the influence of sublethal concentrations of A. belladonna herbal extract.

The lowest value of eggs laid per female was found in the $\mathrm{LC}_{30}$ treatment. Therefore, the treated mites with this concentration will produce the least population in their second generation. However according to Binaghi et al (2014) the total fecundity of two-spotted spider mite in control group were 64.44 per female and 32.46 and 31.08 eggs for cumin and clove essential oil treatments respectively. Also the results of present study is consistent that the findings reported by Castagnoli et al. (2005), Numa et al. (2011) and Sivira et al. (2011), who observed that increasing the concentration of the extract applied to $T$. urticae adults, cause to reducing the fercundity of the phytophagous females. In another study, Refaat et al. (2002) investigated two essential oils, Ocimum basilicum L. (Lamiaceae) and Lavandula of Ficinalis Chaix (Lam-iaceae) on T. urticae. Their results showed that both essential oils have significant reduction in the total number of eggs laid by this mite.

Table 2. Effects of sublethal concentration of Atropa belladonna herbal extract on reproductive parameters of Tetranychus urticae

\begin{tabular}{lllll}
\hline Parameter & Control & $\mathbf{L C}_{\mathbf{1 0}}$ & $\mathbf{L C}_{\mathbf{2 0}}$ & $\mathbf{L C}_{\mathbf{3 0}}$ \\
\hline Pre-oviposition Period (day) & $1.00 \pm 0.00 \mathrm{a}$ & $1.00 \pm 00.0 \mathrm{a}$ & $1.00 \pm 0.00 \mathrm{a}$ & $1.02 \pm 0.02 \mathrm{a}$ \\
Oviposition Period (day) & $10.74 \pm 0.09 \mathrm{a}$ & $9.80 \pm 0.13 \mathrm{~b}$ & $8.94 \pm 0.15 \mathrm{c}$ & $7.06 \pm 0.08 \mathrm{~d}$ \\
TPOP (day) & $11.79 \pm 0.13 \mathrm{a}$ & $11.62 \pm 0.13 \mathrm{a}$ & $11.5 \pm 0.12 \mathrm{a}$ & $11.26 \pm 0.11 \mathrm{~b}$ \\
Total fecundity (offspring/individual) & $55.57 \pm 0.50 \mathrm{a}$ & $46.45 \pm 0.7 \mathrm{~b}$ & $37.62 \pm 0.94 \mathrm{c}$ & $27.39 \pm 0.51 \mathrm{~d}$
\end{tabular}

Note. TPOP: total pre-oviposition period. Means within a row followed by the letter are not significantly different. The \pm SE were estimated by using 100,000 bootstraps and compared by using paired bootstraps test at $5 \%$ significance level. 


\subsection{Population Parameters}

The demographic parameters of $T$. urticae affected by sublethal treatments of $A$. belladonna herbal extract are depicted in Table 3. GRR decreased significantly with increasing sublethal concentrations. Net reproductive rate $\left(R_{0}\right)$ in the $\mathrm{LC}_{30}$ dose was significantly inferior to other treatments. Given that the amount of $R_{0}$ depends on the number of eggs produced and the survival rate, the data indicated a low survival and oviposition rate in the treated population. The highest and lowest values of $R_{0}$ were 18.08 and 38.41 offspring/individual, respectively, for control and $\mathrm{LC}_{30}$ treatment. Assessed intrinsic rate of increase for mites influenced by sublethal doses was ranged of 0.2201 to 0.1937 day $^{-1}$. Also, in mites treated with different doses of Atropa belladonna herbal extract, the values of $r$ and $\lambda$ were significantly less than control.

A. belladonna herbal extract caused a reduction in longevity, survival and fecundity of T. urticae and thereby causes a reduction in $r_{m}$. The higher $r$ value, population increase is faster and growth period is shorter. The results that obtained from this study is consistent with reported by Gholamzadeh Chitgar et al. (2013) that noted population parameters of T. urticae that treated by Thymus vulgaris essential oil had a significant difference at $r$, $R_{0}, T$ and $\lambda$ parameters. Therefore, it can be concluded that the doses used from the extract reduce the growth potential of TSSM in comparison with the control. The results are similar to those reported by Binaghi et al. (2014) that cumin and clove oil reduces the growth potential of two spotted spider mite population. The average of a mean generation time needs 16.55 and 14.93 days in control and $\mathrm{LC}_{30}$ concentration.

The lowest average generation length was observed for the $\mathrm{LC}_{30}$ dose of the treated mites $(\mathrm{P}<0.0001, \mathrm{df}=3)$. Kumral et al. (2013) reported that leaf extract of D. stramonium had toxic and repellent effect both on P. ulmi and its predator Stethorus gilvifrons (Muls.) (Coleoptera: Coccinellidae).

Table 3. Life table parameters (mean $\pm \mathrm{SE}$ ) of offspring from females of Tetranychus urticae treated with sublethal concentrations of Atropa belladonna herbal extract

\begin{tabular}{lllll}
\hline Parameters & Control & $\mathbf{L C}_{\mathbf{1 0}}$ & $\mathbf{L C}_{\mathbf{2 0}}$ & $\mathbf{L C}_{\mathbf{3 0}}$ \\
\hline$G R R$ (offspring/individual) & $48.34 \pm 2.89 \mathrm{a}$ & $38.44 \pm 2.28 \mathrm{~b}$ & $30.47 \pm 1.91 \mathrm{c}$ & $21.36 \pm 1.36 \mathrm{~d}$ \\
$R_{0}$ (offspring/individual) & $38.41 \pm 3.14 \mathrm{a}$ & $30.66 \pm 2.24 \mathrm{~b}$ & $24.82 \pm 1.89 \mathrm{c}$ & $18.08 \pm 1.34 \mathrm{~d}$ \\
$r\left(\right.$ day $\left.^{-1}\right)$ & $0.2201 \pm 0.005 \mathrm{a}$ & $0.2117 \pm 0.004 \mathrm{a}$ & $0.2033 \pm 0.005 \mathrm{a}$ & $0.1937 \pm 0.005 \mathrm{ab}$ \\
$\lambda$ (day $\left.^{-1}\right)$ & $1.246 \pm 0.006 \mathrm{a}$ & $1.235 \pm 0.006 \mathrm{a}$ & $1.225 \pm 0.006 \mathrm{a}$ & $1.213 \pm 0.006 \mathrm{ab}$ \\
$T$ (days) & $16.55 \pm 0.12 \mathrm{a}$ & $16.15 \pm 0.11 \mathrm{~b}$ & $15.77 \pm 0.10 \mathrm{c}$ & $14.93 \pm 0.09 \mathrm{~d}$ \\
\hline
\end{tabular}

Note. Means within a row followed by the same letter are not significantly different. The \pm SE were estimated by using 100,000 bootstraps and compared by using paired bootstraps test at $5 \%$ significance level.

\subsection{Survival and Fecundity}

Figure 2, compares the $l_{x}$, of $T$. urticae at different concentration of Atropa belladonna herbal extract. The total life time for untreated mites was scored 26 days, while it was 25,24 and 22 days for the mites treated at $\mathrm{LC}_{10}$, $\mathrm{LC}_{20}$ and $\mathrm{LC}_{30}$ of experimental concentrations.

The age-specific fecundity $\left(m_{x}\right)$ curves for both treated and untreated mites are depicted in Figure 3 . The maximum values of $m_{x}$ was 4.74 eggs/individual/day for control which was occurred on $21^{\text {th }}$ day of lifespan. This value were estimated to be $3.95,3.69,3.39$ eggs/individual/day that were happened on $17,15,15^{\text {th }}$ day which were recorded for the mites treated at $\mathrm{LC}_{10}, \mathrm{LC}_{20}$ and $\mathrm{LC}_{30}$, respectively.

The age-stage survival rate $\left(S_{x j}\right)$ indicated chance that a T. uricae egg will survive to age $x$ and stage $j$ (Figure 4). This curve indicated overlaps due to the varation in different life stages of T. urticae. The highest female and male survival rate obtained $69 \%$ and $23 \%$ in control (female) and $\mathrm{LC}_{10}, \mathrm{LC}_{20}$ and $\mathrm{LC}_{30}$ (male) treatment respectively. 

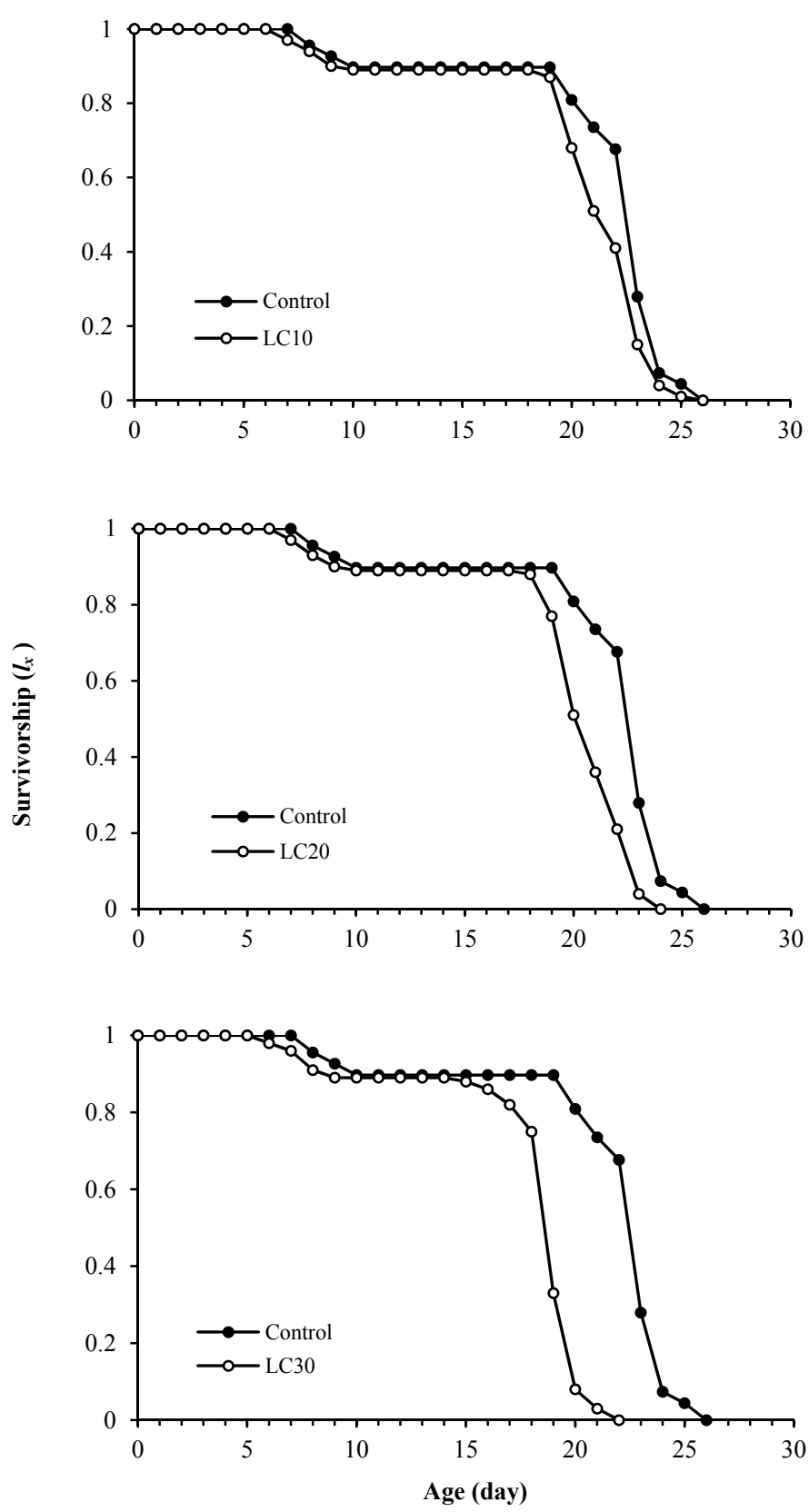

Figure 2. Age-specific survivorship ( $l x)$ of offspring of the treated and untreated mites of Tetranychus urticae by of Atropa belladonna extract 

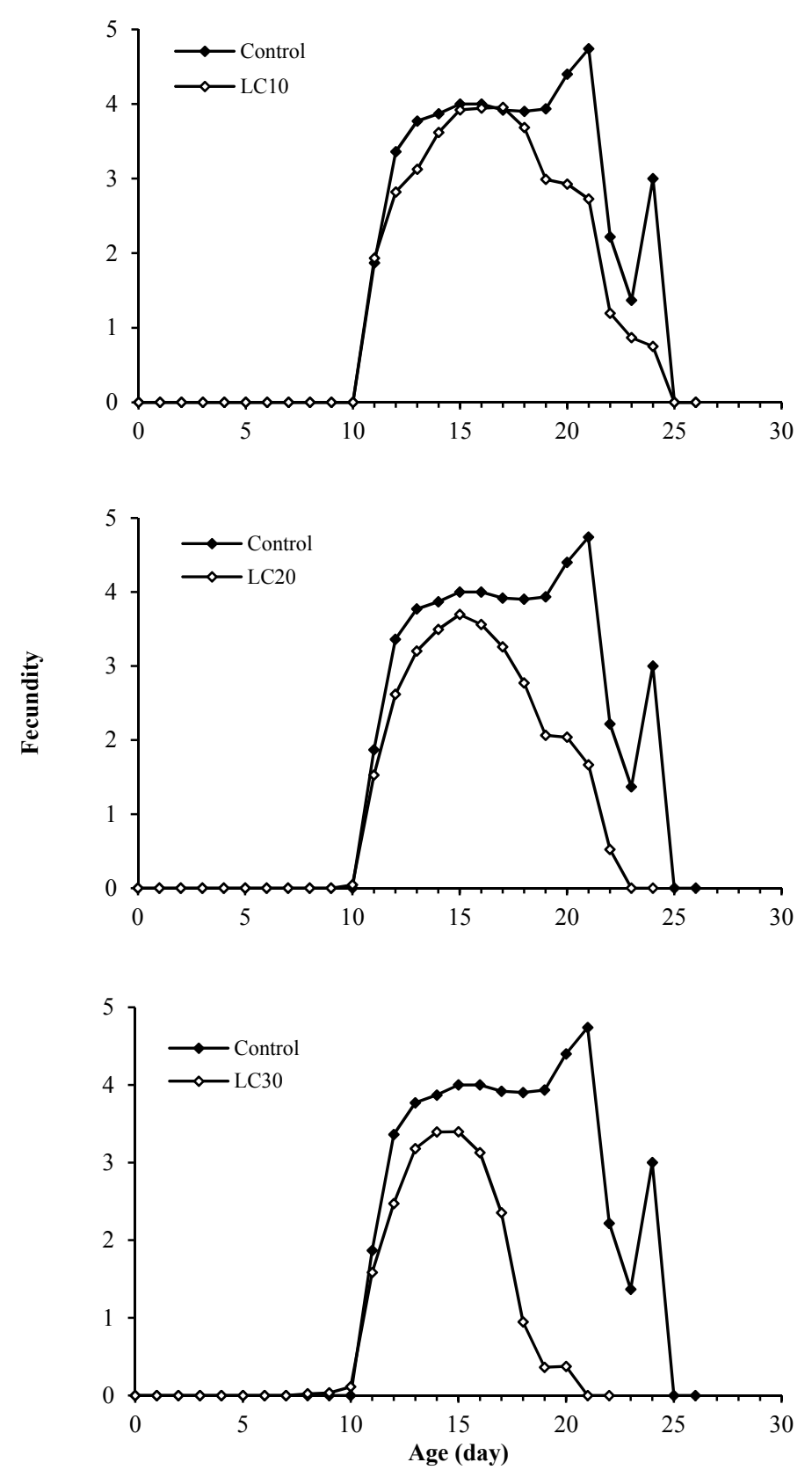

Figure 3. Age-specific fecundity $\left(m_{x}\right)$ of the offspring of the treated and untreated mites of Tetranychus urticae by Atropa belladonna extract 


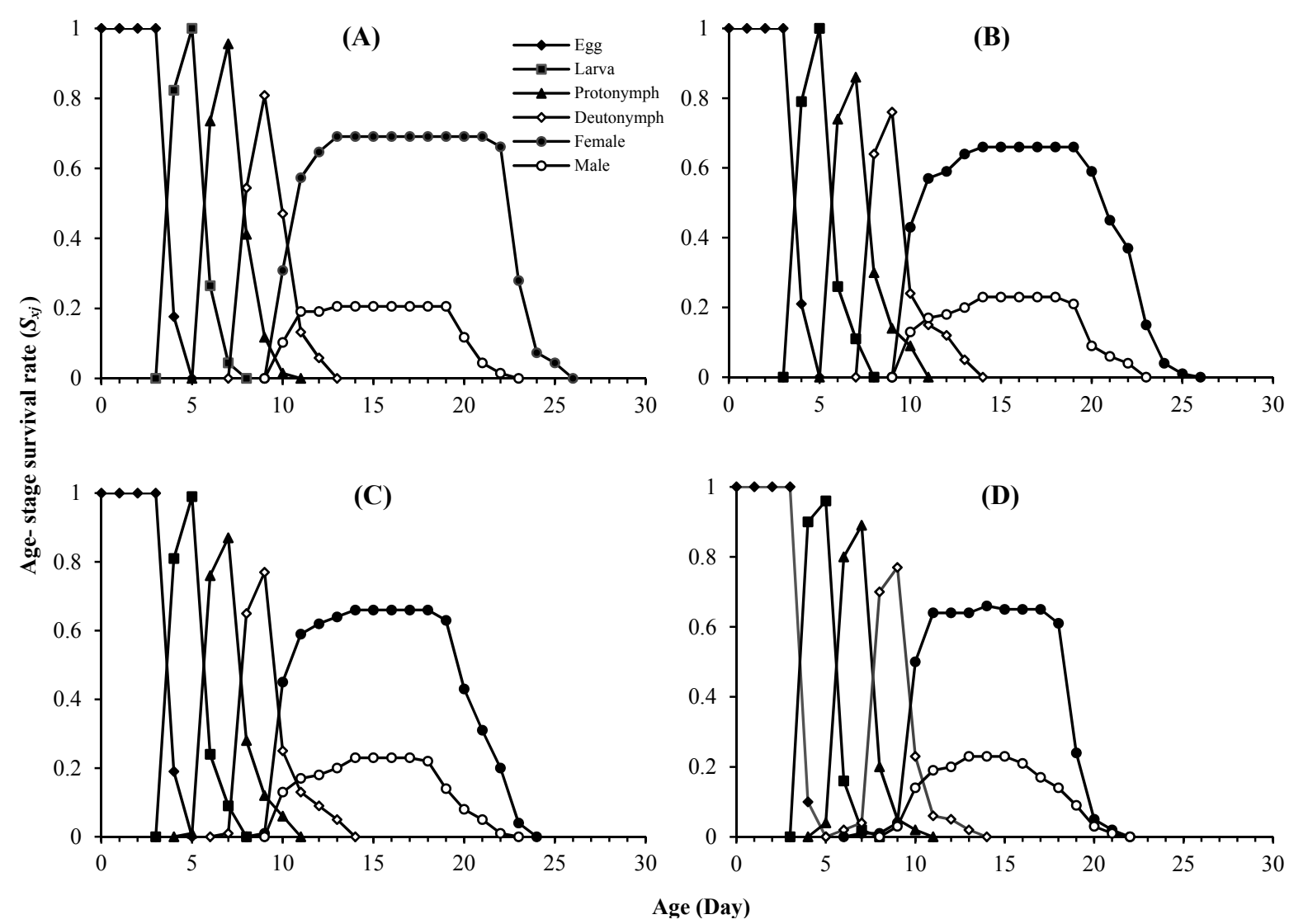

Figure 4. Age-stage specific survival rate $\left(s_{x j}\right)$ of Tetranychus urticae for control and different concentrations of Atropa belladonna herbal extract: Control (A), $\mathrm{LC}_{10}$ (B), $\mathrm{LC}_{20}(\mathrm{C}), \mathrm{LC}_{30}$ (D)

According to the OECD (Organisation for Economic Co-operation and Development) guidance biopesticides should only be authorized if they pose minimal or no risk to mammals, other non-target organisms and the environment (Marcic \& Medo, 2014). This study provides the population parameters and demographic data related to offspring in treated T. urticae with sublethal concentrations of Atropa belladonna herbal extract. Our results clearly showed that Atropa belladonna herbal extract can be consid-ered as an acaricide against the two spotted spider mite, causing reduction in fecundity and longevity in the laboratory at concentrations. This herbal extract is a promising natural alternative for the control of $T$. urticae. Pesticides based on plant or their constituents have demonstrated efficacy against a range of stored product pests (Gholamzadeh Chitgar et al., 2013).

The results of this study showed that the application of the Atropa belladonna herbal extract has effects on the Tetranychus urticae population. The $\mathrm{LC}_{30}$ concentration caused a higher mortality in mites population than $\mathrm{LC}_{20}$ and $\mathrm{LC}_{10}$. It also reduced the parameters such as the immature period. Also the life span both of the sex. This herbal extract has an impact on population growth and reproductive rates of TSSM and can cause a decrease in the population treated in the next generation. Consequently, it is recommended that apply sublethal concentrations of Atropa belladonna herbal extract at lower rates could lead to efficient control of T. urticae.

\section{References}

Bakkali, F., Averbeck, S., Averbeck, D., \& Idaomar, M. (2008). Biological effects of essential oils-A review. Food and Chemical Toxicology, 46, 446-475. https://doi.org/10.1016/j.fct.2007.09.106

Berdai, M. A., Labib, S., Chetouani, K., \& Harandou, M. (2012). Case Report-Atropa Belladonna intoxication: A case report. Pan African Medical Journal, 11(1).

Bolland, H. R., Gutierrez, J., \& Flechtmann, C. H. (1998). World catalogue of the spider mite family (Acari: Tetranychidae) (p. 392). Brill Publicaion, Leiden. 
Boykin, L. S., \& Campbell, W. V. (1982). Rate of population increase of the two spotted spider mite (Acari: Tetranychidae) on peanut leaves treated with pesticides. Journal of Economic Entomology, 75, 966-971. https://doi.org/10.1093/jee/75.6.966

Brattsten, L. B., Holyoke, C. W., \& Leeper, J. R. (1986). Insecticide resistance: challenge to pest management and basic research. Science, 231, 1255-1260. https://doi.org/10.1126/science.231.4743.1255

Castagnoli, M., Liguori, M., Simoni, S., \& Duso, C. (2005). Toxicity of some insecticides to Tetranychus urticae, Neoseiulus californicus and Tydeus californicus. Biocontrol, 50, 611-622. https://doi.org/10.1007/ s10526-004-8121-7

Cavalcanti, S. C. H., Niculau, E. S., Blank, A. F., Câmara, I. N., Araújo, I. N., \& Alves, P. B. (2010). Composition and acaricidal activity of Lippia sidoides essential oil against two-spotted spider mite (Tetranychus urticae Koch). Bioresource Technology, 101, 829-832. https://doi.org/10.1016/j.biortech.2009. 08.053

Chi, H. (1988). Life-table analysis incorporating both sexes and variable development rates among individuals. Environmental Entomology, 17(1), 26-34. https://doi.org/10.1093/ee/17.1.26

Chi, H. (2016). Twosex-Mschart: A computer program for the age-stage, two-sex life table analysis.

Chi, H. S. I. N., \& Liu, H. (1985). Two new methods for the study of insect population ecology. Bulletin of the Institute of Zoology, Academia Sinica, 24(2), 225-240.

Choi, W. I., Lee, S. G., Park, H. M., \& Ahn, Y. J. (2004). Toxicity of plant essential oils to Tetranychus urticae (Acari: Tetranychidae) and Phytoseiulus persimilis (Acari: Phytoseiidae). Journal of Economic Entomology, 97(2), 553-558. https://doi.org/10.1093/jee/97.2.553

Cote, K. W., Lewis, E. E., \& Schultz, P. B. (2002). Compatibility of acaricide residues with Phytoseiulus persimilis and their effects on Tetranychus urticae. HortScience, 37(6), 906-909.

Croft, B. A. (1990). Arthropod biological control agents and pesticides. John Wiley, New York.

de Freitas Fernandes, F., \& Freitas, E. D. P. S. (2007). Acaricidal activity of an oleoresinous extract from Copaifera reticulata (Leguminosae: Caesalpinioideae) against larvae of the southern cattle tick, Rhipicephalus (Boophilus) microplus (Acari: Ixodidae). Veterinary Parasitology, 147(1), 150-154. https://doi.org/10.1016/j.vetpar.2007.02.035

Elzen, G. W. (2001). Lethal and Sublethal Effects of Insecticide Residues on Orius insidiosus (Hemiptera: Anthocoridae) and Geocoris punctipes (Hemiptera: Lygaeidae). Journal of Economic Entomology, 94(1), 55-59. https://doi.org/10.1603/0022-0493-94.1.55

Fathipour, Y., \& Maleknia, B. (2016). Mite predators. Ecofriendly pest management for food security (pp. 329-366). https://doi.org/10.1016/B978-0-12-803265-7.00011-7

Garcia-Mar1, F., \& Gonzalez-Zamora, J. E. (1999). Biological control of Tetranychus urticae (Acari: Tetranychidae) with naturally occurring predators in strawberry plantings in Valencia, Spain. Experimental and Applied Acarology, 23(6), 487-495. https://doi.org/10.1023/A:1006191519560

Gholamzadeh Chitgar, M., Khosravi, R., JalaliSendi, J., \& Ghadamyari, M. (2013). Sublethal effects of Thymus vulgaris essential oil on life-table parameters of two-spotted spider mite, Tetranychus urticae Koch (Acari: Tetranychidae). Archives of Phytopathology and Plant Protection, 46(7), 781-788. https://doi.org/10.1080/ 03235408.2012 .752143

Goodman, D. (1982). Optimal life histories, optimal notation, and the value of reproductive value. The American Naturalist, 119(6), 803-823. https://doi.org/10.1086/283956

Han, J., Choi, B. R., Lee, S. G., Kim, S. I., \& Ahn, Y. J. (2010). Toxicity of Plant Essential Oils to AcaricideSusceptible and -Resistant Tetranychus urticae (Acari: Tetranychidae) and Neoseiulus californicus (Acari: Phytoseiidae). Journal of Economic Entomology, 103(4), 1293-1298. https://oi.org/10.1603/ EC09222

Helle, W., \& Overmeer, W. P. J. (1985). Toxicological test methods. In W. Helle, \& M. W. Sabelis (Eds.), Spider Mites. Their Biology, Natural Enemies and Control (Vol. 1A, pp. 391-395). Elsevier, Amsterdam, Oxford, New York, Tokyo.

Helle, W., \& Sabelis, M. W. (1985). Spider mites: Their biology, natural enemies and control (Vol. 1, p. 403). Amsterdam: Elsevier. 
Kay, Q. O. N. (1992). Edible fruits in a cool climate: the evolution and ecology of endozoochory in the European flora. Seminar Series-Society for Experimental Biology. https://doi.org/10.1017/CBO9780511752322.012

Khanamani, M., Fathipour, Y., \& Hajiqanbar, H. (2013). Population growth response of Tetranychus urticae to eggplant quality: Application of female age-specific and age-stage, two-sex life tables. International Journal of Acarology, 39(8), 638-648.

Khanamani, M., Fathipour, Y., Talebi, A. A., \& Mehrabadi, M. (2017). Linking pollen quality and performance of Neoseiulus californicus (Acari: Phytoseiidae) in two-spotted spider mite management programmes. Pest Management Science, 73(2), 452-461.

Kim, S. I., Roh, J. Y., Kim, D. H., Lee, H. S., \& Ahn, Y. J. (2003). Insecticidal activities of aromatic plant extracts and essential oils against Sitophilus oryzae and Callosobruchus chinensis. Journal of Stored Products Research, 39(3), 293-303. https://doi.org/10.1016/S0022-474X(02)00017-6

Kumral, N. A., Çobanoğlu, S., \& Yalcin, C. (2010). Acaricidal, repellent and oviposition deterrent activities of Datura stramonium L. against adult Tetranychus urticae (Koch). Journal of Pest Science, 83(2), 173-180. https://doi.org/10.1007/s10340-009-0284-7

Kumral, N. A., Çobanoğlu, S., \& Yalçın, C. (2013). Sub-lethal and lethal effects of Datura stramonium L. leaf extracts on the European red mite Panonychus ulmi (Koch) (Acari: Tetranychidae) and its predator, Stethorus gilvifrons (Muls.) (Col.: Coccinellidae). International Journal of Acarology, 39(6), 494-501. https://doi.org/10.1080/01647954.2013.826279

Maleknia, B., Fathipour, Y., \& Soufbaf, M. (2016). How greenhouse cucumber cultivars affect population growth and two-sex life table parameters of Tetranychus urticae (Acari: Tetranychidae). International Journal of Acarology, 42(2), 70-78.

Marčić, D., \& Medo, I. (2014). Acaricidal activity and sublethal effects of an oxymatrine-based biopesticide on two-spotted spider mite (Acari: Tetranychidae). Experimental and Applied Acarology, 64(3), 375-391. https://doi.org/10.1007/s10493-014-9831-x

Numa, V. S. J., Bustos, H. A., Rodriguez, C. D., \& Cantor, R. F. (2011). Laboratory and greenhouse evaluation of the entomopathogenic fungi and garlic-pepper extract on the predatory mites, Phytoseiulus persimilis and Neosuiulus californicus and their effect on the spider mite Tetranychus urticae. Biol Control, 57, 143-149. https://doi.org/10.1016/j.biocontrol.2011.02.007

Ofuya, T. I., \& Okuku, I. E. (1994). Insecticidal effect of some plant extracts on the cowpea aphidAphis craccivora Koch (Homoptera: Aphididae). Anzeiger für Schädlingskunde, 67(6), 127-129. https://doi.org/ 10.1007/BF01909033

Pavela, R. (2015). Acaricidal properties of extracts and major furanochromenes from the seeds of Ammi visnaga Linn. against Tetranychus urticae Koch. Industrial Crops and Products, 67, 108-113. https://doi.org/ 10.1016/j.indcrop.2015.01.011

Poletti, M., Maia, A. H. N., \& Omoto, C. (2007). Toxicity of neonicotinoid insecticides to Neoseiulus californicus and Phytoseiulus macropilis (Acari: Phytoseiidae) and their impact on functional response to Tetranychus urticae (Acari: Tetranychidae). Biological Control, 40(1), 30-36. https://doi.org/10.1016/ j.biocontrol.2006.09.001

Refaat, M., Momen, M., \& Amer, S. A. A. (2002). Acaricidal activity of sweet basil and French lavender essential oils against two species of mites of the family Tetranychidae (Acari: Tetranychidae). Acta Phytopatho Entomol Hungarica, 37, 287-298. https://doi.org/10.1556/APhyt.37.2002.1-3.28

Riahi, E., Fathipour, Y., Talebi, A. A., \& Mehrabadi, M. (2017). Attempt to Develop Cost-Effective Rearing of Amblyseius swirskii (Acari: Phytoseiidae): Assessment of Different Artificial Diets. Journal of Economic Entomology, 110(4), 1525-1532.

Rim, I. S., \& Jee, C. H. (2006). Acaricidal effects of herb essential oils against Dermatophagoides farinae and D. pteronyssinus (Acari: Pyroglyphidae) and qualitative analysis of a herb Mentha pulegium (pennyroyal). The Korean Journal of Parasitology, 44(2), 133. https://doi.org/10.3347/kjp.2006.44.2.133

Rita, P., \& Animesh, D. K. (2011). An updated overview on Atropa belladonna L. International Research Journal of Pharmacy, 2, 11-17. 
Saeidi, Z., \& Arbabi, M. (2007). Effectiveness of 12 pesticides against two infestation levels of bean fields by Tetranychus urticae Koch in Lordegan, Chaharmahal and Bakhtiari province. Pajouhesh and Sazandegi, 76, 25-31.

SAS Institute. (2002). SAS/STAT User's Guide (Version 9.2). Cary, NC: SAS Institute.

Sedaratian, A., Fathipour, Y., \& Moharramipour, S. (2009). Evaluation of resistance in 14 soybean genotypes to Tetranychus urticae (Acari: Tetranychidae). Journal of Pest Science, 82(2), 163-170.

Singh, J., Singh, R. N., \& Rai, S. N. (2002). Expanding pest status of phytophagous mites and integrated pest management. IPM System in Agriculture, 7, 1-29.

Sivira, A., Sanabria, M. E., Valera, N., \& Vásquez, C. (2011). Toxicity of Ethanolic Extracts from Lippia origanoides and Gliricidia sepium to Tetranychus cinnabarinus (Boisduval) (Acari: Tetranychidae). Neotrop Entomol, 40(3), 375-379.

Teodoro, A. V., Fadini, M. A., Lemos, W. P., Guedes, R. N. C., \& Pallini, A. (2005). Lethal and sub-lethal selectivity of fenbutatin oxide and sulfur to the predator Iphiseiodes zuluagai (Acari: Phytoseiidae) and its prey, Oligonychus ilicis (Acari: Tetranychidae), in Brazilian coffee plantations. Experimental and Applied Acarology, 36(1), 61-70. https://doi.org/10.1007/s10493-005-0507-4

Tsolakis, H., \& Ragusa, S. (2008). Effects of a mixture of vegetable and essential oils and fatty acid potassium salts on Tetranychus urticae and Phytoseiulus persimilis. Ecotoxicology and Environmental Safety, 70, 276-282. https://doi.org/10.1016/j.ecoenv.2007.10.001

Zhang, Z. Q. (2003). Mites of greenhouses: Identification, biology and control (p. 244). CABI. https://doi.org/ 10.1079/9780851995908.0000

Zhao, S. H. (2000). Plant Chemical Protection (pp. 250-253). China Agriculture Press, Beijing, China.

\section{Copyrights}

Copyright for this article is retained by the author(s), with first publication rights granted to the journal.

This is an open-access article distributed under the terms and conditions of the Creative Commons Attribution license (http://creativecommons.org/licenses/by/4.0/). 